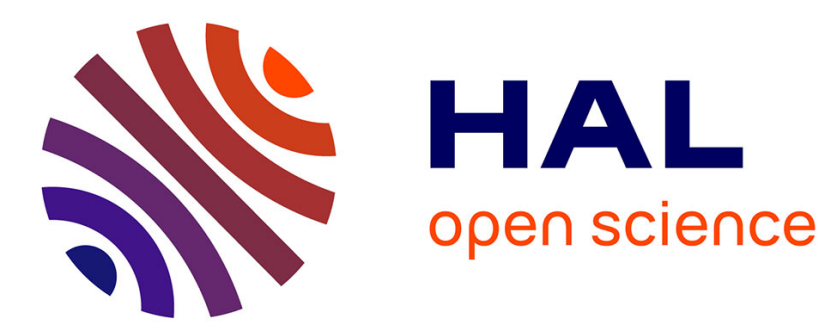

\title{
Extension of a wide-range three-step hydrogen mechanism to syngas
}

Pierre Boivin, Forman A. Williams

\section{To cite this version:}

Pierre Boivin, Forman A. Williams. Extension of a wide-range three-step hydrogen mechanism to syngas. Combustion and Flame, 2018, 196, pp.85-87. 10.1016/j.combustflame.2018.05.034 . hal02112081

\section{HAL Id: hal-02112081 https: / hal-amu.archives-ouvertes.fr/hal-02112081}

Submitted on 26 Apr 2019

HAL is a multi-disciplinary open access archive for the deposit and dissemination of scientific research documents, whether they are published or not. The documents may come from teaching and research institutions in France or abroad, or from public or private research centers.
L'archive ouverte pluridisciplinaire HAL, est destinée au dépôt et à la diffusion de documents scientifiques de niveau recherche, publiés ou non, émanant des établissements d'enseignement et de recherche français ou étrangers, des laboratoires publics ou privés. 
archives-ouvertes

\section{Extension of a wide-range three-step hydrogen mechanism to syngas}

Pierre Boivin, Forman Williams

\section{To cite this version:}

Pierre Boivin, Forman Williams. Extension of a wide-range three-step hydrogen mechanism to syngas. Combustion and Flame, Elsevier, 2018, 196, pp.85 - 87. 10.1016/j.combustflame.2018.05.034 . hal01822166

\section{HAL Id: hal-01822166 \\ https://hal.archives-ouvertes.fr/hal-01822166}

Submitted on 24 Jun 2018

HAL is a multi-disciplinary open access archive for the deposit and dissemination of scientific research documents, whether they are published or not. The documents may come from teaching and research institutions in France or abroad, or from public or private research centers.
L'archive ouverte pluridisciplinaire HAL, est destinée au dépôt et à la diffusion de documents scientifiques de niveau recherche, publiés ou non, émanant des établissements d'enseignement et de recherche français ou étrangers, des laboratoires publics ou privés. 


\title{
Extension of a Wide-Range Three-Step Hydrogen Mechanism to Syngas
}

\author{
P. Boivin ${ }^{1 \mathrm{a}}$, F. A. Williams ${ }^{\mathrm{b}}$ \\ ${ }^{a}$ Aix Marseille Univ, CNRS, Centrale Marseille, M2P2, Marseille, France \\ ${ }^{b}$ Dept. of Mechanical and Aerospace Engineering, University of California San Diego, La \\ Jolla CA 92093-0411, USA
}

Keywords: combustion, syngas, reduced chemistry, autoignition

Previously [1] we have shown how a single species X can be introduced, representing either $\mathrm{HO}_{2}$ for high-temperature ignition or $\mathrm{H}_{2} \mathrm{O}_{2}$ for low-temperature ignition, to develop an algorithm that covers the entire range of ignition, flame-propagation, and combustion conditions, without a significant degradation of accuracy, for hydrogen-air systems. By adding relevant CO chemistry to the hydrogen chemistry, this same approach can be applied to derive a comparably useful four-step reduced-chemistry description for syngas blends that have small enough concentrations of methane, other hydrocarbons, or other reactive species to be dominated by the elementary steps of the $\mathrm{H}_{2} / \mathrm{CO}$ system. The present communication reports the resulting extended algorithm.

This work begins with the elementary steps of the detailed chemistry as listed in Table 1. We shall employ the numbering of the steps as given in the table, which identifies the 8 steps that are considered to be reversible and gives fitted parameters for the reverses of those steps. There are 18 entries in

\footnotetext{
${ }^{1}$ Corresponding author: pierre.boivin@univ-amu.fr 


\begin{tabular}{|c|c|c|c|c|c|c|c|c|c|}
\hline & Reaction & & $A^{\mathrm{a}}$ & $n$ & $E^{\mathrm{a}}$ & & $A^{\mathrm{a}}$ & $n$ & $E^{\mathrm{a}}$ \\
\hline 1 & $\mathrm{H}+\mathrm{O}_{2} \rightleftharpoons \mathrm{OH}+\mathrm{O}$ & $k_{f}$ & $3.5210^{16}$ & -0.7 & 71.42 & $k_{b}$ & $7.0410^{13}$ & -0.26 & 0.60 \\
\hline 2 & $\mathrm{H}_{2}+\mathrm{O} \rightleftharpoons \mathrm{OH}+\mathrm{H}$ & $k_{f}$ & $5.0610^{4}$ & 2.67 & 26.32 & $k_{b}$ & $3.0310^{4}$ & 2.63 & 20.23 \\
\hline 3 & $\mathrm{H}_{2}+\mathrm{OH} \rightleftharpoons \mathrm{H}_{2} \mathrm{O}+\mathrm{H}$ & $k_{f}$ & $1.1710^{9}$ & 1.3 & 15.21 & $k_{b}$ & $1.2810^{10}$ & 1.19 & 78.25 \\
\hline 4 & $\mathrm{H}+\mathrm{O}_{2}+\mathrm{M} \rightarrow \mathrm{HO}_{2}+\mathrm{M}^{\mathrm{b}}$ & $k_{0}$ & $5.7510^{19}$ & -1.4 & 0.0 & $k_{\infty}$ & $4.6510^{12}$ & 0.44 & 0.0 \\
\hline 5 & $\mathrm{HO}_{2}+\mathrm{H} \rightarrow 2 \mathrm{OH}$ & & $7.0810^{13}$ & 0.0 & 1.23 & & & & \\
\hline 6 & $\mathrm{HO}_{2}+\mathrm{H} \rightleftharpoons \mathrm{H}_{2}+\mathrm{O}_{2}$ & $k_{f}$ & $1.6610^{13}$ & 0.0 & 3.44 & $k_{b}$ & $2.6910^{12}$ & 0.36 & 231.86 \\
\hline 7 & $\mathrm{HO}_{2}+\mathrm{OH} \rightarrow \mathrm{H}_{2} \mathrm{O}+\mathrm{O}_{2}$ & & $2.8910^{13}$ & 0.0 & -2.08 & & & & \\
\hline 8 & $\mathrm{H}+\mathrm{OH}+\mathrm{M} \rightleftharpoons \mathrm{H}_{2} \mathrm{O}+\mathrm{M}^{\mathrm{c}}$ & $k_{f}$ & $4.0010^{22}$ & -2.0 & 0.0 & $k_{b}$ & $1.0310^{23}$ & -1.75 & 496.14 \\
\hline 9 & $2 \mathrm{H}+\mathrm{M} \rightleftharpoons \mathrm{H}_{2}+\mathrm{M}^{\mathrm{d}}$ & $k_{f}$ & $1.3010^{18}$ & -1.0 & 0.0 & $k_{b}$ & $3.0410^{17}$ & -0.65 & 433.09 \\
\hline 10 & $2 \mathrm{HO}_{2} \rightarrow \mathrm{H}_{2} \mathrm{O}_{2}+\mathrm{O}_{2}$ & & $1.0310^{14}$ & 0.0 & 46.2 & + & $1.9410^{11}$ & 0.0 & -5.9 \\
\hline 11 & $\mathrm{HO}_{2}+\mathrm{H}_{2} \rightarrow \mathrm{H}_{2} \mathrm{O}_{2}+\mathrm{H}$ & & $7.8010^{10}$ & 0.61 & 100.14 & & & & \\
\hline 12 & $\mathrm{H}_{2} \mathrm{O}_{2}+\mathrm{M} \rightarrow 2 \mathrm{OH}+\mathrm{M}^{\mathrm{e}}$ & $k_{0}$ & $8.1510^{23}$ & -1.9 & 207.62 & $k_{\infty}$ & $2.6310^{19}$ & -1.27 & 214.74 \\
\hline 13 & $\mathrm{CO}+\mathrm{OH} \rightleftharpoons \mathrm{CO}_{2}+\mathrm{H}$ & $k_{f}$ & $4.410^{6}$ & 1.5 & -3.1 & $k_{b}$ & $2.4110^{13}$ & 0.22 & 104.60 \\
\hline 14 & $\mathrm{CO}+\mathrm{HO}_{2} \rightarrow \mathrm{CO}_{2}+\mathrm{OH}$ & & $6.0310^{13}$ & 0.0 & 96.0 & & & & \\
\hline 15 & $\mathrm{HCO}+\mathrm{M} \rightleftharpoons \mathrm{CO}+\mathrm{H}+\mathrm{M}^{\mathrm{f}}$ & $k_{f}$ & $1.8610^{17}$ & -1 & 71.13 & $k_{b}$ & $3.5110^{16}$ & -0.77 & 5.35 \\
\hline 16 & $\mathrm{HCO}+\mathrm{H} \rightarrow \mathrm{CO}+\mathrm{H}_{2}$ & & $5.010^{13}$ & 0.0 & 0.0 & & & & \\
\hline 17 & $\mathrm{CO}+\mathrm{O}_{2} \rightarrow \mathrm{CO}_{2}+\mathrm{O}$ & & $1.010^{12}$ & 0.0 & 199.6 & & & & \\
\hline 18 & $\mathrm{CO}+\mathrm{O}+\mathrm{M} \rightleftharpoons \mathrm{CO}_{2}+\mathrm{M}^{\mathrm{g}}$ & $k_{0}$ & $1.5510^{24}$ & -2.8 & 17.6 & $k_{\infty}$ & $1.8010^{11}$ & 0.0 & 23.8 \\
\hline
\end{tabular}

Table 1: Rate coefficients in Arrhenius form $k=A T^{n} \exp \left(-E / R^{o} T\right)$ for the skeletal mechanism.

${ }^{a}$ Units are mol, $\mathrm{s}, \mathrm{cm}^{3}, \mathrm{~kJ}$, and $\mathrm{K}$.

${ }^{b}$ Chaperon efficiencies are 2.5 for $\mathrm{H}_{2}, 16.0$ for $\mathrm{H}_{2} \mathrm{O}, 1.2$ for $\mathrm{CO}, 2.4$ for $\mathrm{CO}_{2}, 0.7$ for $\mathrm{Ar}$ and $\mathrm{He}$ and 1.0 for all other species; Troe falloff with $F_{c}=0.5$

${ }^{c}$ Chaperon efficiencies are 2.5 for $\mathrm{H}_{2}, 12.0$ for $\mathrm{H}_{2} \mathrm{O}, 1.9$ for $\mathrm{CO}, 3.8$ for $\mathrm{CO}_{2}, 0.5$ for $\mathrm{Ar}$ and $\mathrm{He}$ and 1.0 for all other species.

${ }^{d}$ Chaperon efficiencies are 2.5 for $\mathrm{H}_{2}, 12.0$ for $\mathrm{H}_{2} \mathrm{O}, 1.9$ for $\mathrm{CO}, 3.8$ for $\mathrm{CO}_{2}, 0.38$ for $\mathrm{Ar}$ and $\mathrm{He}$ and 1.0 for all other species.

${ }^{e}$ Chaperon efficiencies are 2.0 for $\mathrm{H}_{2}, 6.0$ for $\mathrm{H}_{2} \mathrm{O}, 1.5$ for $\mathrm{CO}, 2.0$ for $\mathrm{CO}_{2}, 0.4$ for $\mathrm{Ar}$ and He and 1.0 for all other species; $F_{c}=0.265 \exp (-T / 94 \mathrm{~K})+0.735 \exp (-T / 1756 \mathrm{~K})+$ $\exp (-5182 \mathrm{~K} / T)$

${ }^{f}$ Chaperon efficiencies are 1.9 for $\mathrm{H}_{2}, 12.0$ for $\mathrm{H}_{2} \mathrm{O}, 2.5$ for $\mathrm{CO}, 2.5$ for $\mathrm{CO}_{2}$ and 1.0 for all other species.

${ }^{g}$ Chaperon efficiencies are 2.5 for $\mathrm{H}_{2}, 12.0$ for $\mathrm{H}_{2} \mathrm{O}, 2.0$ for $\mathrm{CO}, 4.0$ for $\mathrm{CO}_{2}, 0.7$ for $\mathrm{Ar}$ and He and 1.0 for all other species. 
this table, two more than in our previous work [2] on reduced chemistry for syngas, because we have found, since that earlier study, that at low $\mathrm{H}_{2}$ levels entry 17 is important as an additional initiation step, and radical removal by entry 18 appreciably affects predicted laminar burning velocities at higher pressures. The listed rate parameters are up-dated values from previous work [3], now available on the same web site, employing more recent evaluations of elementary rate coefficients for hydrogen [4]. In particular, for step 10 we now realize that, to account properly for the two paths, a bi-Arrhenius expression is needed, employing the sum of two Arrhenius terms with the different sets of rate parameters listed.

Steady-state approximations are first introduced for $\mathrm{O}, \mathrm{OH}$, and $\mathrm{HCO}$, resulting in a 5-step mechanism that can be written as:

$$
\begin{gathered}
3 \mathrm{H}_{2}+\mathrm{O}_{2} \stackrel{\mathrm{I}}{\rightleftharpoons} 2 \mathrm{H}_{2} \mathrm{O}+2 \mathrm{H}, \quad 2 \mathrm{H}+\mathrm{M} \stackrel{\mathrm{II}}{\rightleftharpoons} \mathrm{H}_{2}+\mathrm{M}, \quad \mathrm{H}_{2}+\mathrm{O}_{2} \stackrel{\text { III }}{\rightleftharpoons} \mathrm{HO}_{2}+\mathrm{H}, \\
\mathrm{CO}+\mathrm{H}_{2} \mathrm{O} \stackrel{\mathrm{IV}}{\rightleftharpoons} \mathrm{CO}_{2}+\mathrm{H}_{2}, \quad \mathrm{H}_{2}+\mathrm{O}_{2} \stackrel{\mathrm{V}}{\rightleftharpoons} \mathrm{H}_{2} \mathrm{O}_{2},
\end{gathered}
$$

with associated rates:

$$
\begin{gathered}
\omega_{\mathrm{I}}=\omega_{1}+\omega_{5 f}+\omega_{12 f}+\omega_{14 f}+\omega_{17 f}, \quad \omega_{\mathrm{II}}=\omega_{4 f}+\omega_{8}+\omega_{9}+\omega_{12 f}-\omega_{15}+\omega_{18 f}, \\
\omega_{\mathrm{III}}=\omega_{4 f}-\omega_{5 f}-\omega_{6}-\omega_{7 f}-2 \omega_{10 f}-\omega_{11 f}-\omega_{14 f}, \\
\omega_{\mathrm{IV}}=\omega_{13}+\omega_{14 f}+\omega_{17 f}+\omega_{18 f}, \quad \omega_{\mathrm{V}}=\omega_{10 f}+\omega_{11 f}-\omega_{12 f},
\end{gathered}
$$

where the $\omega_{i}$ refer to the rates of the $i^{t h}$ elementary step listed in Table 1. The concentrations of the steady-state species, needed for evaluating these rates, are given as supplementary material for $\mathrm{OH}(7), \mathrm{O}(8)$ and $\mathrm{HCO}(9)$. As explained previously [1, 2, 5, 6], the steady states for $\mathrm{O}$ and $\mathrm{OH}$, which hold with reasonable accuracy in flames, do not apply during autoignition 
and lead to significant underpredictions of induction times, with increasing errors for decreasing equivalence ratios. A correction to the branching rate therefore must be made and can be obtained by introducing the modified $\operatorname{rates} \omega_{\mathrm{I}}^{*} / \omega_{\mathrm{I}}=\omega_{\mathrm{II}}^{*} / \omega_{\mathrm{II}}=\omega_{\mathrm{III}}^{*} / \omega_{\mathrm{III}}=\omega_{\mathrm{IV}}^{*} / \omega_{\mathrm{IV}}=\Lambda$, where the factor

$$
\Lambda=\left[(1+2 B)^{1 / 2}-1\right] / B
$$

depends on the forward rates of the shuffle reactions 1-3 and the CO-consumption reaction 13 through

$$
B=\frac{4 k_{1 f} C_{\mathrm{O}_{2}}\left(k_{1 f} C_{\mathrm{O}_{2}}+k_{2 f} C_{\mathrm{H}_{2}}+k_{3 f} C_{\mathrm{H}_{2}}+k_{13 f} C_{\mathrm{CO}}\right)}{k_{2 f} C_{\mathrm{H}_{2}}\left(k_{3 f} C_{\mathrm{H}_{2}}+k_{13 f} C_{\mathrm{CO}}\right)},
$$

the term in $\mathrm{B}$ arising from step 13, not needed for $\mathrm{H}_{2}$ and not employed previously [2] for syngas, but having been found in the present study to improve predictions and to be preferable to an ad hoc revision introduced previously [7]. The modifications are switched off by setting $\Lambda=1$ where the steady states for $\mathrm{O}$ and $\mathrm{OH}$ apply, that is, in hot regions with relatively high radical concentrations, where the $\mathrm{HO}_{2}$ steady state also holds. For this reason, the need for the correction factor is linked to the failure of the $\mathrm{HO}_{2}$ steady state; the rate of $\mathrm{HO}_{2}$ production $\dot{C}_{\mathrm{HO}_{2 P}}=\omega_{4 f}+\omega_{6 b}$ and that of $\mathrm{HO}_{2}$ consumption $\dot{C}_{\mathrm{HO}_{2 C}}=\omega_{5 f}+\omega_{6 f}+\omega_{7 f}+2 \omega_{10 f}+\omega_{11 f}+\omega_{14 f}$ are to be evaluated locally and checked to see if their fractional difference is sufficiently small (for example, less than 0.05), in which case the modifications are discontinued.

The first of the two adjacent 4-step mechanisms is obtained by assuming $\mathrm{H}_{2} \mathrm{O}_{2}$ to be steady state, an approximation applicable in the high-temperature regime, and the second is derived by assuming $\mathrm{HO}_{2}$ to be in steady state, applicable in the low-temperature regime. 
At high temperatures, the mechanism consists of steps I, II, III, and IV, with associated rates:

$$
\begin{aligned}
& \omega_{\mathrm{I}}^{+}=\omega_{1}+\omega_{5 f}+\omega_{10 f}+\omega_{11 f}+\omega_{14 f}+\omega_{17 f}, \\
& \omega_{\mathrm{II}}^{+}=\omega_{4 f}+\omega_{8}+\omega_{9}-\omega_{10 f}-\omega_{11 f}-\omega_{15}, \\
& \omega_{\mathrm{III}}^{+}=\omega_{4 f}-\omega_{5 f}-\omega_{6}-\omega_{7 f}-2 \omega_{10 f}-\omega_{11 f}-\omega_{14 f}, \\
& \omega_{\mathrm{IV}}^{+}=\omega_{13}+\omega_{14 f}+\omega_{17 f},
\end{aligned}
$$

the expressions needed for steady-state concentrations being (17), (8), and (9), along with (11), all being provided as supplementary material.

The reduced mechanism applicable at low temperatures consists of steps I, II, IV, and V (step III disappearing with the $\mathrm{HO}_{2}$ steady-state assumption), and the rate of step II must be modified from (1) to read

$$
\omega_{\text {II }}=\omega_{4 f}+\omega_{8}+\omega_{9}-\omega_{10 f}-\omega_{11 f}-\omega_{15}+\omega_{18 f} .
$$

The expressions for $C_{\mathrm{O}}, C_{\mathrm{OH}}$, and $C_{\mathrm{HCO}}$ steady states are the same as those for the 5-step description (7), (8), and (9). The $\mathrm{HO}_{2}$ concentration, now needed in evaluating the global rates, is given by (10), the steady-state formula (11) for $\mathrm{H}_{2} \mathrm{O}_{2}$ having been discarded.

Despite not consisting of the same global steps, the two adjacent 4-step reduced mechanisms, can be written as a single universal reduced mechanism

$$
\begin{gathered}
3 \mathrm{H}_{2}+\mathrm{O}_{2} \stackrel{\mathrm{I}}{\rightleftharpoons} 2 \mathrm{H}_{2} \mathrm{O}+2 \mathrm{H}, \quad 2 \mathrm{H}+\mathrm{M} \stackrel{\mathrm{II}}{\rightleftharpoons} \mathrm{H}_{2}+\mathrm{M}, \quad \mathrm{CO}+\mathrm{H}_{2} \mathrm{O} \stackrel{\mathrm{IV}}{\rightleftharpoons} \mathrm{CO}_{2}+\mathrm{H}_{2}, \\
\mathrm{H}_{2}+\mathrm{O}_{2} \stackrel{\mathrm{III}}{\rightleftharpoons} \mathrm{X}+\mathrm{H} .
\end{gathered}
$$

Because the mass and diffusive properties of $\mathrm{HO}_{2}$ and $\mathrm{H}_{2} \mathrm{O}_{2}$ are similar, $\mathrm{X}$ can represent either $\mathrm{HO}_{2}$, when the $\omega^{+}$of (4) are used as global rates, or 
$\mathrm{H}_{2} \mathrm{O}_{2}$, in the low-temperature regime, when the rates $\omega^{-}$, given below, are used. As discussed in [1], the global rates for the 4-step reduced mechanism at low temperatures cannot be used directly for the universal reduced mechanism because that would lead to an overproduction of $\mathrm{H}$ atoms - a byproduct of step III, not of $\mathrm{V}$. This is avoided by turning the $\mathrm{H}$ overproduction into an overproduction of $\mathrm{H}_{2}$, which we found negligible in all cases tested. The resulting applicable low-temperature rates for the universal reduced mechanism then become

$$
\begin{gathered}
\omega_{\mathrm{I}}^{-}=\omega_{1}+\omega_{5 f}+\omega_{12 f}+\omega_{14 f}+\omega_{17 f}, \\
\omega_{\mathrm{II}}^{-}=\omega_{4 f}+\omega_{8}+\omega_{9}-\left(\omega_{10 f}+\omega_{11 f}+\omega_{12 f}\right) / 2-\omega_{15}+\omega_{18 f}, \\
\omega_{\mathrm{III}}^{-}=\omega_{10 f}+\omega_{11 f}-\omega_{12 f}, \quad \omega_{\mathrm{IV}}^{-}=\omega_{13}+\omega_{14 f}+\omega_{17 f}+\omega_{18 f},
\end{gathered}
$$

to be evaluated with $C_{\mathrm{O}}, C_{\mathrm{OH}}, C_{\mathrm{HCO}}$, and $C_{\mathrm{HO}_{2}}$ steady-state expressions (7), (8)), (9), and (10). Following the strategy presented in [1], when the two mechanisms are merged into one,

$$
\begin{cases}\omega=\omega^{-} & \text {if }\left(\omega_{P}-\omega_{C}\right) / \omega_{P}<\varepsilon \\ \omega=\omega^{+} & \text {if }\left(\omega_{P}-\omega_{C}\right) / \omega_{P}>\varepsilon\end{cases}
$$

with

$\omega_{P}=2 \omega_{1 f}+\omega_{6 b}+\omega_{11 f}+2 \omega_{12 f}+2 \omega_{14 f}+\omega_{17 f}, \quad \omega_{C}=\omega_{4 f}+2 \omega_{15 b}+\omega_{18 f}$,

which are approximations for the H-atom production and consumption rates, to be evaluated using the steady-state expression (10) for $C_{\mathrm{HO}_{2}}$ as an approximation. The value of $\varepsilon$ must be sufficiently small (in our implementation, $\varepsilon=0.05)$. 
This completes the specification of the algorithm that, for syngas, comprises a 4-step description that will produce results as accurate of those of the original 5-step reduced mechanism. The 4-step reduced description has the same applicability as our initial reduced mechanism [2] (ie. premixed and non-premixed combustion, as well as detonations and autoignition above the second explosion limit), now extended to include autoignition below the

second limit as well. Computations from our initial contribution [2] were repeated as validation tests and are included as supplementary material.

\section{Acknowledgements}

This work was carried out during a summer stay of P. Boivin at UCSD, supported by Labex MEC (ANR-10-LABX-0092) and the A*MIDEX project (ANR-11-IDEX-0001-02), funded by the "Investissements d'Avenir".

\section{Source files}

The source files for the mechanism are available at www.pierreboivin.info, in the "Reduced Kinetics" Section. A tutorial to implement reduced kinetics in Cantera [13] is also provided there.

[1] P. Boivin, A. L. Sánchez, F. A. Williams, Four-step and three-step systematically reduced chemistry for wide-range $\mathrm{H}_{2}$-air combustion problems, Combustion and Flame 160 (1) (2013) 76-82.

[2] P. Boivin, C. Jiménez, A. L. Sánchez, F. A. Williams, A four-step reduced mechanism for syngas combustion, Combustion and Flame 158 (6) (2011) 1059-1063. 
[3] P. Saxena, F. Williams, Testing a small detailed chemical-kinetic mechanism for the combustion of hydrogen and carbon monoxide, Combustion and Flame 145 (1-2) (2006) 316-323.

[4] A. L. Sánchez, F. A. Williams, Recent advances in understanding of flammability characteristics of hydrogen, Progress in Energy and Combustion Science 41 (2014) 1-55.

[5] P. Boivin, A. L. Sánchez, F. A. Williams, Explicit analytic prediction for hydrogen-oxygen ignition times at temperatures below crossover, Combustion and Flame 159 (2) (2012) 748-752.

[6] P. Boivin, A. Sánchez, F. Williams, Analytical prediction of syngas induction times, Combustion and Flame 176 (2017) 489-499.

[7] Z. M. Nikolaou, J.-Y. Chen, N. Swaminathan, A 5-step reduced mechanism for combustion of $\mathrm{co} / \mathrm{h} 2 / \mathrm{h} 2 \mathrm{o} / \mathrm{ch} 4 / \mathrm{co} 2$ mixtures with low hydrogen/methane and high h2o content, Combustion and Flame 160 (1) (2013) 56-75.

[8] F. Williams, et al., Chemical-kinetic mechanisms for combustion applications, University of California, San Diego, http://web.eng.ucsd.edu/mae/groups/combustion/mechanism.html.

[9] H. Sun, S. Yang, G. Jomaas, C. Law, High-pressure laminar flame speeds and kinetic modeling of carbon monoxide/hydrogen combustion, Proceedings of the Combustion Institute 31 (1) (2007) 439-446.

[10] I. C. McLean, D. B. Smith, S. C. Taylor, The use of carbon monoxide/hydrogen burning velocities to examine the rate of the $\mathrm{CO}+\mathrm{OH}$ 
reaction, Proceedings of the Combustion Institute 25 (1) (1994) 749757.

[11] C. Dong, Q. Zhou, Q. Zhao, Y. Zhang, T. Xu, S. Hui, Experimental study on the laminar flame speed of hydrogen/carbon monoxide/air mixtures, Fuel 88 (10) (2009) 1858-1863.

[12] D. Kalitan, J. Mertens, M. Crofton, E. Petersen, Ignition and oxidation of lean CO/H2 fuel blends in air, Journal of Propulsion and Power 23 (6) (2007) 1291-1303.

[13] D. G. Goodwin, H. K. Moffat, R. L. Speth, Cantera: An object-oriented software toolkit for chemical kinetics, thermodynamics, and transport processes, http: //www . cantera.org (2017). 


\section{Supplementary material}

Steady state formulas

The steady state formulas needed for the reduced descriptions read

$$
\begin{aligned}
C_{\mathrm{OH}} & =\left[\left(A_{1}^{2}+4 A_{0} A_{2}\right)^{1 / 2}-A_{1}\right] /\left(2 A_{2}\right), \\
C_{\mathrm{O}} & =\frac{k_{1 f} C_{\mathrm{H}} C_{\mathrm{O}_{2}}+k_{2 b} C_{\mathrm{OH}} C_{\mathrm{H}}+k_{17 f} C_{\mathrm{CO}} C_{\mathrm{O}_{2}}}{k_{1 b} C_{\mathrm{OH}}+k_{2 f} C_{\mathrm{H}_{2}}}, \\
C_{\mathrm{HCO}} & =\frac{k_{15 b} C_{\mathrm{CO}} C_{\mathrm{H}} C_{\mathrm{M}}}{k_{15 f} C_{\mathrm{M}}+k_{16 f} C_{\mathrm{H}}},
\end{aligned}
$$

where the expressions

$$
\begin{aligned}
A_{0}= & \left(k_{2 f} C_{\mathrm{H}_{2}}+k_{18 f} C_{\mathrm{CO}} C_{\mathrm{M}}\right)\left(2 k_{1 f} C_{\mathrm{H}} C_{\mathrm{O}_{2}}+k_{3 b} C_{\mathrm{H}} C_{\mathrm{H}_{2} \mathrm{O}}+2 k_{5 f} C_{\mathrm{H}} C_{\mathrm{HO}_{2}}+k_{8 b} C_{\mathrm{M}} C_{\mathrm{H}_{2} \mathrm{O}}\right. \\
& \left.+2 k_{12 f} C_{\mathrm{H}_{2} \mathrm{O}_{2}} C_{\mathrm{M}}+k_{13 b} C_{\mathrm{CO}_{2}} C_{\mathrm{H}}+k_{14 f} C_{\mathrm{CO}} C_{\mathrm{HO}_{2}}\right)+C_{\mathrm{CO}} C_{\mathrm{O}_{2}}\left(k_{2 f} k_{17 f} C_{\mathrm{H}_{2}}-k_{1 f} k_{18 f} C_{\mathrm{H}}\right), \\
A_{1}= & \left(k_{2 f} C_{\mathrm{H}_{2}}+k_{18 f} C_{\mathrm{CO}} C_{\mathrm{M}}\right)\left(k_{3 f} C_{\mathrm{H}_{2}}+k_{7 f} C_{\mathrm{HO}_{2}}+k_{8 f} C_{\mathrm{M}} C_{\mathrm{H}}+k_{13 f} C_{\mathrm{CO}}\right) \\
& -k_{1 b}\left(k_{3 b} C_{\mathrm{H}} C_{\mathrm{H}_{2} \mathrm{O}}+2 k_{5 f} C_{\mathrm{H}} C_{\mathrm{HO}_{2}}+k_{8 b} C_{\mathrm{M}} C_{\mathrm{H}_{2} \mathrm{O}}+2 k_{12 f} C_{\mathrm{H}_{2} \mathrm{O}_{2}} C_{\mathrm{M}}\right. \\
& \left.+k_{13 b} C_{\mathrm{CO}_{2}} C_{\mathrm{H}}+k_{14 f} C_{\mathrm{CO}} C_{\mathrm{HO}_{2}}+k_{17 f} C_{\mathrm{CO}} C_{\mathrm{O}_{2}}\right)+k_{2 b} k_{18 f} C_{\mathrm{H}} C_{\mathrm{CO}} C_{\mathrm{M}}, \\
A_{2}= & k_{1 b}\left(k_{3 f} C_{\mathrm{H}_{2}}+k_{7 f} C_{\mathrm{HO}_{2}}+\left(2 k_{2 b}+k_{8 f} C_{\mathrm{M}}\right) C_{\mathrm{H}}+k_{13 f} C_{\mathrm{CO}}\right) .
\end{aligned}
$$

are to be used to evaluate the $\mathrm{OH}$ concentration from (7) prior to calculating the $\mathrm{O}$ concentration from (8)).

$$
\begin{gathered}
C_{\mathrm{HO}_{2}}=\left(B_{2}^{2}+B_{1}\right)^{1 / 2}-B_{2}, \\
B_{1}=\left(k_{6 b} C_{\mathrm{H}_{2}} C_{\mathrm{O}_{2}}+k_{4 f} C_{\mathrm{H}} C_{\mathrm{O}_{2}} C_{\mathrm{M}_{4}}\right) /\left(2 k_{10 f}\right) \\
B_{2}=\left(k_{5 f} C_{\mathrm{H}}+k_{6 f} C_{\mathrm{H}}+k_{7 f} C_{\mathrm{OH}}+k_{11 f} C_{\mathrm{H}_{2}}+k_{14 f} C_{\mathrm{CO}}\right) /\left(4 k_{10 f}\right) \\
C_{\mathrm{H}_{2} \mathrm{O}_{2}}=\frac{k_{10 f} C_{\mathrm{HO}_{2}}^{2}+k_{11 f} C_{\mathrm{HO}_{2}} C_{\mathrm{H}_{2}}}{k_{12 f} C_{\mathrm{M}}}
\end{gathered}
$$




\section{Validation}

The applicability of the 4-step reduced mechanism is similar to that of our initial contribution [2], with additional inclusion of high-pressure (or lowtemperature) autoignition thanks to the hybrid species description. Figures 1 and 2 repeat some validation computations from [2], showing a similar agreement. Flame velocities as obtained between the reduced and detailed description are within $20 \%$ at atmospheric pressures, and $15 \%$ at higher pressures, of interest for instance in gas-turbine combustion. Agreement between detailed and 4-step descriptions for ignition times is excellent for all conditions of practical interest. 

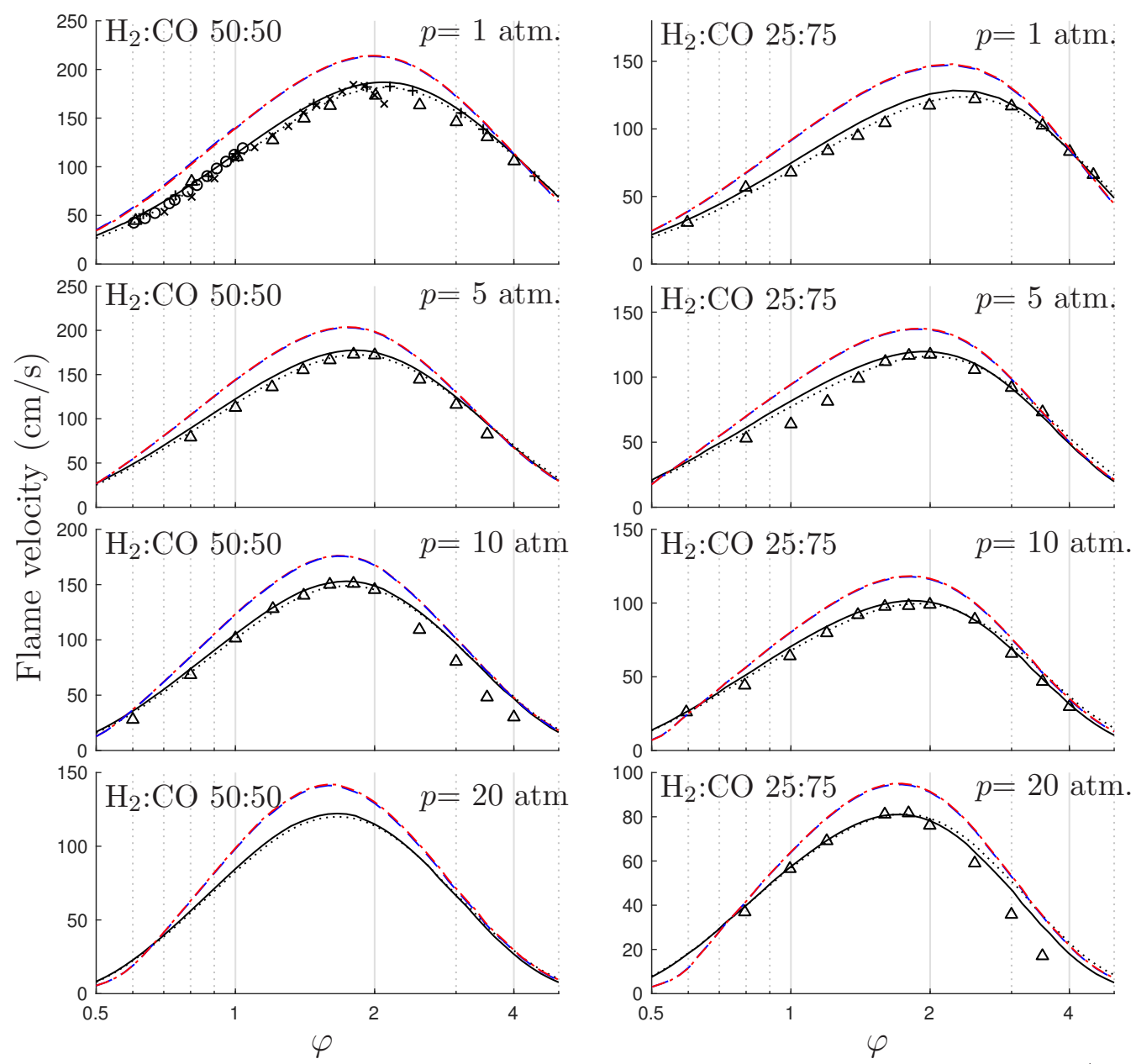

Figure 1: The variation with equivalence ratio of the laminar flame velocity for a $\mathrm{CO} / \mathrm{H}_{2}$ oxidizer mixture at initial temperature $T_{u}=300 \mathrm{~K}$ and for four different pressures and two different $\mathrm{CO} / \mathrm{H}_{2}$ ratios as obtained from numerical integrations with the latest detailed San Diego mechanism [8] (solid curves), 5-step (dashed curves), and 4-step (dot-dashed curves) chemistry descriptions and from laboratory measurements (triangles $\triangle$ : 9 ; crosses + : [10]; times $\times$ : [11]); the oxidizer for $p=1$ atm is air, while for $p=(5,10,20)$ atm it is an oxygen-helium mixture with mole-fraction ratio $X_{\mathrm{He}} / X_{\mathrm{O}_{2}}=7$. [9]. Dotted curves correspond to the detailed San Diego mechanism [8] in its 2009-11-01 version (latest version at time of [2]). Note that the 5 and 4-step reduced chemistry descriptions lead to indistinguishable results. Flame velocities as obtained with the reduced and detailed description are within $20 \%$ at atmospheric pressures, and $15 \%$ at higher pressures. 

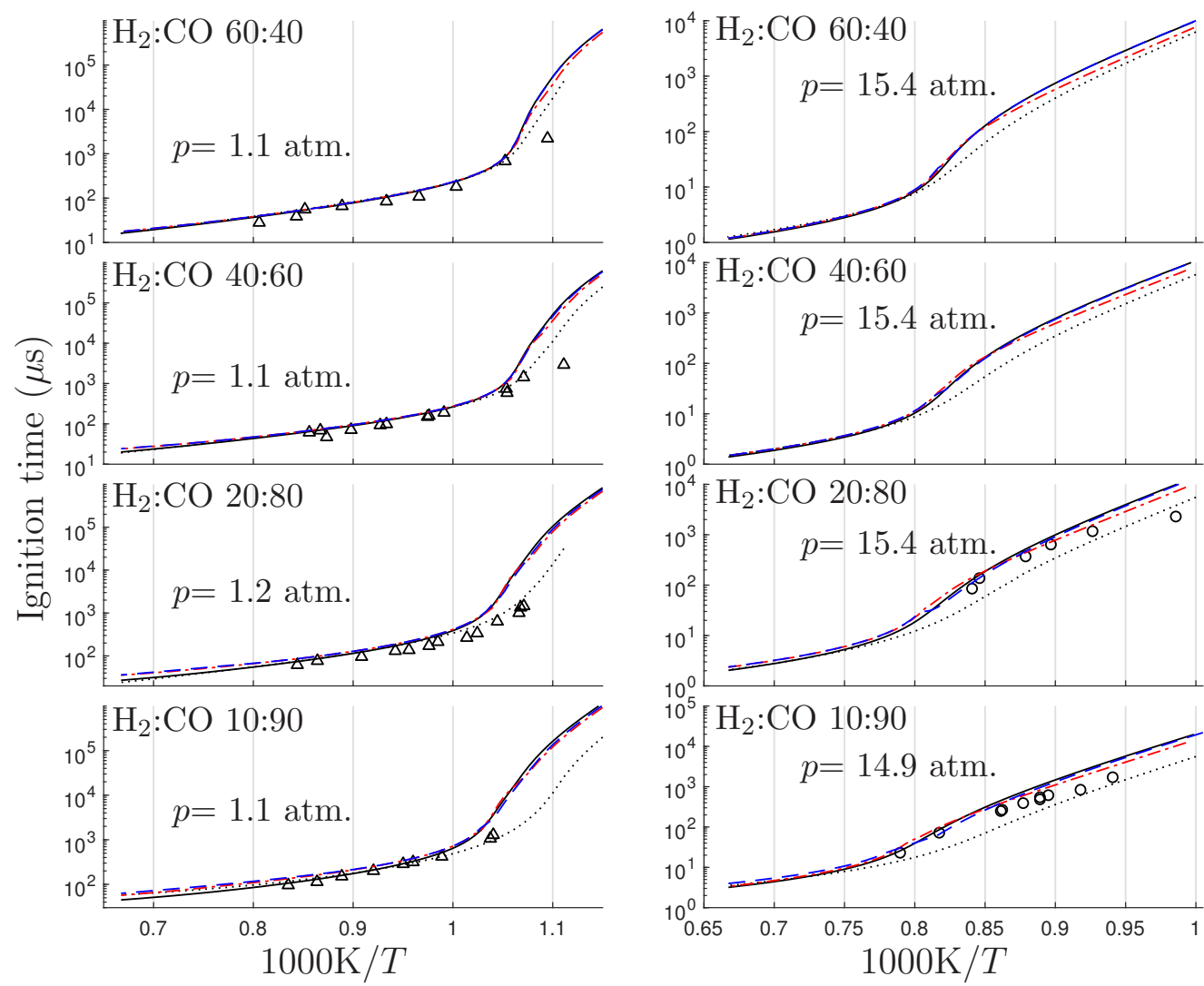

Figure 2: The variation with initial temperature of the induction time for a $\mathrm{CO} / \mathrm{H}_{2}$-air mixture with $\phi=0.5$ as obtained from numerical integrations with the latest detailed San Diego mechanism [8] (solid curves), skeletal mechanism from Tab. 10 (dashed curves), and 4-step reduced (dot-dashed curves) chemistry descriptions and from laboratory measurements (symbols: [12]). Dotted curves correspond to the detailed San Diego mechanism [8] in its 2009-11-01 version (latest version at time of [2]). 